\title{
Foreword
}

\section{Koen Lenaerts}

The power to tax is, without question, one of the key powers inherent in the exercise of national sovereignty. That is because that power provides the necessary means to carry on the business of government and to put into effect redistributive policies defining how a society is to pursue social justice. Moreover, as the American revolutionary rallying cry - 'no taxation without representation' - neatly illustrates, the power to tax must be exercised by democratically-elected officials. Taxation, sovereignty and democracy thus go hand-in-hand.

More than 60 years ago, when the Member States of the European Union (EU) decided to establish a new legal order, possessing its own institutions, for the benefit of which those Member States have limited their sovereign rights, albeit in limited fields, that traditional understanding of taxation had to be adapted to accommodate a new reality. In the EU legal order, national powers of taxation are to be exercised in keeping with 'positive' and 'negative' integration.

Positively, the EU may adopt harmonising measures in the field of taxation that directly affect the establishment or functioning of the internal market. However, given that unanimity within the Council is required and that the role of the European Parliament is limited to that of consultation, the Member States still have the final say as to whether taxes should be subject to common regulatory standards. To date, when it comes to direct taxation, the scope of EU law itself is rather limited: unlike in the tax system of other multi-level systems of governance such as the US, there is no 'EU income tax' and no 'EU corporate tax'. However, some ancillary aspects of direct taxation have been harmonised in order to facilitate free movement. This is the case, for example, of the parent-subsidiary directive that seeks to eliminate double taxation of dividends and other profit distributions paid by subsidiary companies to their parent company. ${ }^{1}$ Similarly, the EU has adopted the corporate-tax-avoidance directive which aims to tackle aggressive tax planning. ${ }^{2}$

Most importantly, it is in the field of indirect taxation where the EU has exercised extensive tax and regulatory powers. The EU enjoys exclusive competence to define and impose customs duties. Moreover, the VAT system is largely defined by EU law, since the EU legislator has harmonised the main features of that tax. ${ }^{3}$ Customs duties and part of the proceeds from VAT go to the EU budget, providing the means for the EU to carry out its policies.

Negatively, EU law may impose limits on the way in which the Member States exercise their power to levy direct taxes. As the Court of Justice of the European Union (the 'Court of Justice') has consistently held, 'whilst direct taxation falls within their competence, the Member States must nonetheless exercise that competence consistently with EU law'. The

Council Directive 2011/96/EU of 30 November 2011 on the common system of taxation applicable in the case of parent companies and subsidiaries of different Member States, [2011] OJ L 345/8.

2 Council Directive (EU) 2016/1164 of 12 July 2016 laying down rules against tax avoidance practices that directly affect the functioning of the internal market, [2016] OJ L 193/1.

3 Council Directive 2006/112/EC of 28 November 2006 on the common system of value added tax, [2006] OJ L 347/1.

4 Judgment of 24 October 2019, Belgian State (Tax exemption for disability allowances), C-35/19, EU:C:2019:894, para. 31 and case law cited. 
Member States thus remain competent to choose the tax base, the tax rate as well as tax allowances and exemptions. Most importantly, they enjoy discretion to decide whether to exercise their taxing powers as a 'home State' (taxing the income of fiscal residents regardless of where it is produced) or alternatively as a 'source State' (taxing the income on a territorial basis even if the taxpayer is not a resident). Relying on the substantive law of the EU - and notably, on the principle of non-discrimination - the Court of Justice has, nonetheless, taken important steps towards 'circumscribing' the exercise of national taxation powers. However, due to the different criteria adopted by national legislators in defining their tax jurisdiction, the Court of Justice has been called upon to fine-tune the principle of non-discrimination according to whether a Member State is acting in a home State or in a source State capacity. In addition to free movement law, recent case law shows that the Treaty provisions on State aid may impose limits on national powers of taxation. In such cases, the difficulty lies in ascertaining whether the tax scheme at issue establishes a selective advantage to the benefit of some undertakings.

Currently, it is thus safe to say that taxation is not 'an island beyond the reach of [EU] law'. ${ }^{5}$ As a matter of fact, in 2018 , more than $10 \%$ of the decisions adopted by the Court of Justice concerned EU taxation law. The ever-growing importance of that field has awakened the interest of legal scholars across Europe. Numerous books, journals and blogs are devoted to studying EU taxation law. Yet scholars tend to focus on a particular aspect of EU taxation law, leaving others unexamined.

That is why the publication Research Handbook on European Union Taxation Law is such a welcome development. Edited by Christiana HJI Panayi, Werner Haslehner and Edoardo Traversa, the Handbook seeks to provide the reader with a holistic analysis of EU taxation law. Given the quality of the editors and contributors - all leading experts in their field of research - it comes as no surprise that the Handbook succeeds in that task.

The Handbook is divided into six parts and contains 28 Chapters. Those impressive numbers reflect not only the breadth of the research contained in it but also the in-depth analysis that has been carried out for each of the topics selected. Part I looks at EU taxation law from a constitutional perspective. It examines the question of competences, the principles that underpin EU taxation law (e.g. the principles of neutrality, equality, territoriality, and the concept of abuse of rights) and the relationship between primary and secondary law, as well as that between EU law and international tax law. Part II focuses on free movement and taxation, paying special attention to the relevant case law. For example, contributors examine the way in which the Court of Justice approaches the question of the comparability of situations between resident and non-resident taxpayers as well as the grounds put forward by the Member State concerned when seeking to justify a difference in treatment. Part III focuses on positive integration, looking at both the harmonising measures adopted by the EU legislator and those that should be adopted to improve the functioning of the internal market. In particular, the VAT system is examined in great detail, in an analysis that encompasses its historical foundations, its main features and the need for legislative reform. In Part IV, the Handbook explores the interplay between competition law and taxation, paying special attention to the recent case law of EU Courts on State aid. Whilst the previous Parts of the Handbook are devoted to studying the substantive aspects of EU taxation law, Part V relates to administrative cooperation and

5 See, by analogy, Opinion of AG Tesauro in Decker, C-120/95, EU:C:1997:399, para. 17. See also Koen Lenaerts, 'Federalism and the Rule of Law: Perspectives from the European Court of Justice' (2009-10) 39 Fordham Int'l L.J. 1338. 
tax procedure, in particular to the exchange of information between national tax authorities that may take place on the basis of secondary EU law. Last but not least, Part VI examines the external dimension of EU taxation law by focusing on three specific topics, i.e. the application of the free movement of capital to third countries, trade and investment agreements and association agreements that have a bearing on national corporate tax systems.

Throughout the book, the contributors do not limit themselves to describing the existing law and case law, but also provide thorough explanations as to the reasons why they believe that the EU legislator and the Court of Justice respectively have reached a given outcome.

Written in a clear and entertaining style, this book succeeds in providing a solid analytical basis for future debate and research on the subject of EU taxation law. It is a thoughtful and rigorous study that addresses a challenging set of questions for scholars and students. Overall, it is an excellent contribution to the legal literature on European Union law and I warmly congratulate both the editors and contributors for it.

Prof. dr. Koen Lenaerts President of the Court of Justice of the European Union 